\title{
Degradation of Riparian Tree Diversity on Spring Fed Drains and Its Impacts to Water Quality, East Java
}

\author{
Chatarina Gradict Semiun*, Endang Arisoesilaningsih, Catur Retnaningdyah
}

Biology Department, Faculty of Mathematics and Natural Sciences, Brawijaya University, Malang, Indonesia

\begin{abstract}
The research aimed at examining the impacts of degradation of riparian tree diversity toward water quality from some springs to their drains in East Java, Indonesia. This descriptive study was conducted in selected springs and their drains in Jember, Kediri, Pasuruan, and Malang from April 2012 to January 2013. Spring water of Meru Betiri National Park was chosen as a reference site. The quality of riparian tree diversity and the water was sampled on three replications. Data were tabulated by statistical analyses using cluster and Spearman correlation. The result showed that there were 69 species belonging to 28 families of riparian tree were found in the springs and their drains. Moraceae was found to be the key family of natural riparian trees, and native trees, except in Kediri, inhabited almost all springs and their drains $(92.75 \%)$. All the observed springs were degrading, compared to the natural one in Meru Betiri National Park where trees grew in strata A to E and showed the highest diversity index $\left(H^{\prime}=3.2\right)$. All springs were found to have high quality of water, but the water in their downstream became so turbid, depending on the quality of riparian tree diversity grown around the springs. The quality of riparian diversity was strongly influenced by land use and human activities such as illegal logging, intensive agriculture, and settlement. There was a positive correlation between riparian tree diversity and water transparency and color; yet, there was a negative correlation with $\mathrm{pH}$ of the water. Low $\mathrm{pH}$, high water transparency and colorless water were found in stations where we found rich tree species, high diversity index, wide and stratified riparian trees.
\end{abstract}

Keywords: diversity quality, riparian tree, spring water, water quality

\section{INTRODUCTION}

Generally, the existing riparian vegetation consists of areas is dominated by native plants such as trees, shrubs, herbs, and grasses [1]. The trees are usually disturbed, especially by human activities. Stream bank vegetation reduces the rate of erosion. Root systems of trees or shrubs protect stream banks from erosion by reinforcing and increasing cohesion of the soil, and by providing protective service matting. Trees use water from the banks, and increase the drainage of the soils that help reducing bank failure due to heavy saturated soil. Riparian vegetation can also play an important role in trapping sediment and its attached pollutants and nutrients before they reach

\footnotetext{
${ }^{*}$ Corresponding author:

Chatarina Gradict Semiun

Biology Department, Faculty of Mathematics and Natural Sciences, Brawijaya University, Jalan Veteran, Malang, Indonesia 65145

E-mail: gr4dict@gmail.com
}

the drains [2].

The existence of natural riparian vegetation is a determinant factor for high or low water quality of water body especially in springs. A spring is an underground source of water emerging naturally on the surface of the ground; may come in a form of intermittent or perennial flow and be discharged at specific locations on earth; and they vary dramatically as to the types of water they discharge [3, 4]. Because of human activities, the quality of spring water has been decreasing [5]. Inappropriate land uses, such as illegal logging, agriculture on sloping land, settlement around the water body, grazing in poor land, etc, can endanger the quality of riparian vegetation $[6,7]$. Land uses, deforestation, the level of nutrients and pesticide application affect the quality of the groundwater [8].

In Indonesia, the studies dealing with riparian vegetation to protect or maintain water quality are still limited or small in number. The number of springs, particularly in East Java, is still abundant. 
In addition, the water from these springs is the main source for organic farming; thus, we need to protect its quality, including the quality of water in canals. The research, therefore, aims at examining the impacts of degradation of riparian tree diversity toward water quality on some springs and their drains in East Java.

\section{MATERIALS AND METHODS}

Almost all the springs observed during the field research were surrounded by riparian vegetation, and almost all of them had been converted, or degraded, because of human activities. The riparian tree vegetation at forestry zones of Blok Aren, in Sanenrejo village, was still natural or free from bad human activities. In the field, the researchers observed the habitat of riparian tree vegetation at the height of less than $1200 \mathrm{~m}$ above sea level (asl), areas categorized as lowland. Meanwhile, the researchers also observed low mountainous areas, at the height of $1290 \mathrm{~m}$ asl, that was in Coban Rondo. Based on the observation, almost all springs have mountain slopes as their borders with the steep of $25-55^{\circ}$ (47-119\%), while their drains have various borders, ranging from flat, going down to slope, a bit steep, steep, and very steep surfaces.

This descriptive study was conducted on selected springs, by observing three sites for each station including Blok Aren Meru Betiri National Park (MBNP) Jember (as a reference site), Kediri, Pasuruan, and Malang. It was done from April 2012 to January 2013. The observed locations were grouped into 9 groups, each of which consists of 3 stations from upstream to downstream. The locations consist of Blok Aren (BA), Andongrejo (AR), Plosolor (Plo), Tempurejo (TR), Bendo (Be), Cowek (Co), Lawang (L), Karangan (K), and Coban Rondo (CR). The field observation included the observation on the quality of riparian tree diversity and quality of water from the springs up to their drains. The variables for riparian tree diversity consist of species and total individual, height, diameter, and stratification. The variables for water quality were $\mathrm{pH}$, measured by $\mathrm{pH}$ meter, electric conductivity, measured by conductivity meter, and visual observation of water transparency and color.

Data were tabulated using Microsoft Excel 2007. A multivariate analysis of cluster and biplot were done employing PAST software to determine the profile of riparian tree diversity (species richness, diversity index, important value index, rate of endemism, and Bray-Curtis similarity index) and water quality profile (cluster and bi-plot analysis). Analysis of Spearman correlation was used to determine the interaction pattern between riparian tree quality and water quality.

\section{RESULTS AND DISCUSSION}

\section{Profile of riparian tree}

Species richness of riparian tree was 69 species belonging to 28 families. The highest species richness was found in Plo1 (13 species), and BA1 (12 species). However, riparian trees were not found on spring and irrigation drains such as Be1, L3, L4, K3, CR2, and CR3 (Figure 1a). The commonest family found on springs and their drains was Moraceae family. This is line with the research report by Soejono (2011) [9] stating that Moraceae family found in springs has high variety. Further, Moraceae is a family with 38 genera and 1100 species wide spread mainly in tropical areas [10]. The riparian trees around springs such as BA1, AR1, Plo1, TR1, L1, K1, and CR1 showed high level of diversity compared to the tree vegetation located around drains (Figure 1b). The highest diversity index was in BA1 $\left(\mathrm{H}^{\prime}=3.2\right)$ and BA2 $\left(H^{\prime}=3.0\right)$ caused by their complexity and density of species richness in each sampling plot.

Naturally, the structure of riparian tree vegetation is composed of various taxa, so it is rare to find a particular species to be dominant. Riparian tree vegetation has some key species such as Artocarpu selasticus, Ceiba petandra, or Dysoxylum amooroides, that can be a domi-nant species. A key species becomes the key stone for the community's structure, in which the integrity and stability of the community are both determined by their activities and abundance [11]. While, the result of the calculation of endemism rate (Figure 2) showed that native trees, except in Kediri (Plo1 and TR2), mostly dominated the tree vegetation on springs and their drains $(92.75 \%)$.

Cluster analysis (Figure 3) showed that generally the tree diversity of springs had great similarity (>80\%), except for CR1, L1, and K1, where riparian trees degraded. The degradation of riparian vegetation could decrease the quality of the habitat due to erosion and sedimentation that could lead to the decrease of water quality [12]. 


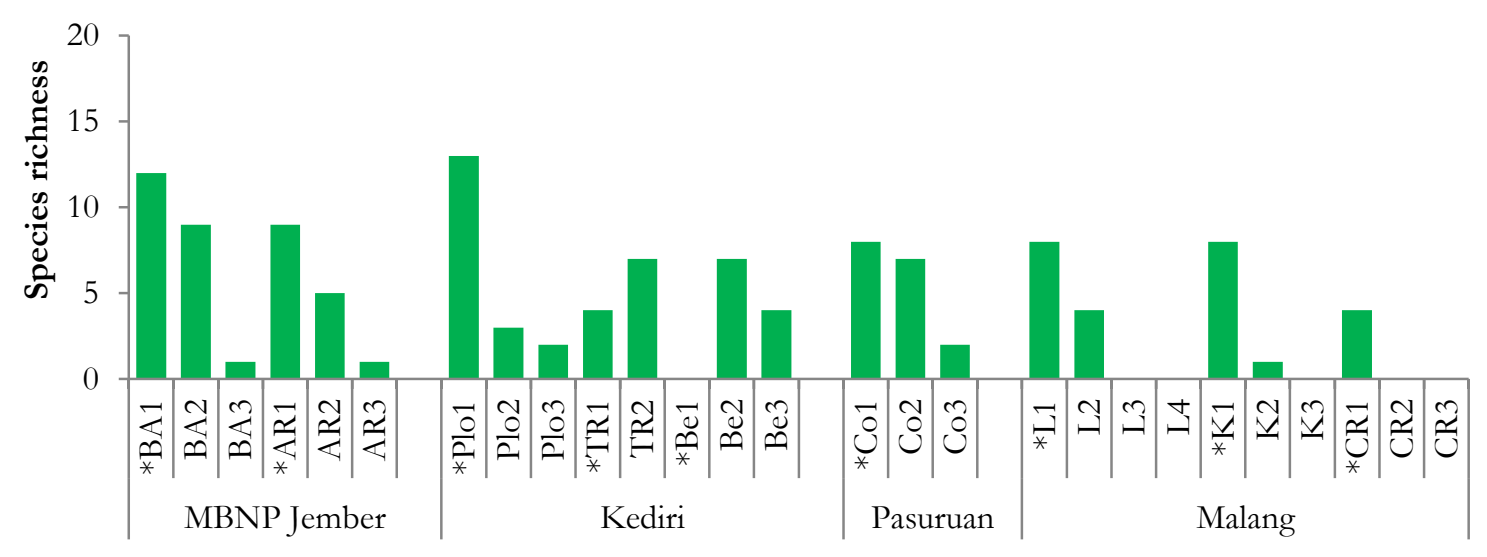

\section{Location}

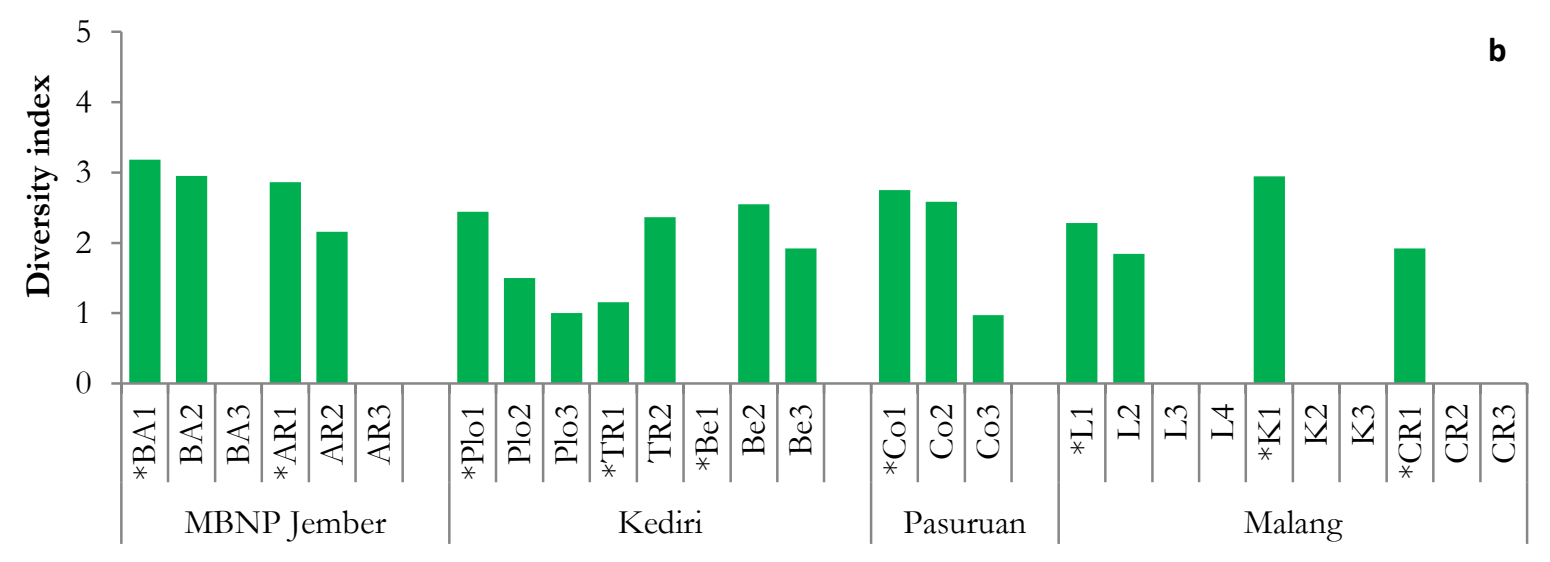

\section{Location}

Figure 1. Species richness of riparian tree (a) and diversity index of riparian tree (b)

Note: ${ }^{*}$ ) Spring; BA = Blok Aren; $\mathrm{AR}=$ Andongrejo; Plo = Plosolor; $\mathrm{TR}=$ Tempurejo; $\mathrm{Be}=$ Bendo; $\mathrm{Co}=$ Cowek; $\mathrm{L}$ = Lawang; $\mathrm{K}=$ Karangan; $\mathrm{CR}=$ Coban Rondo

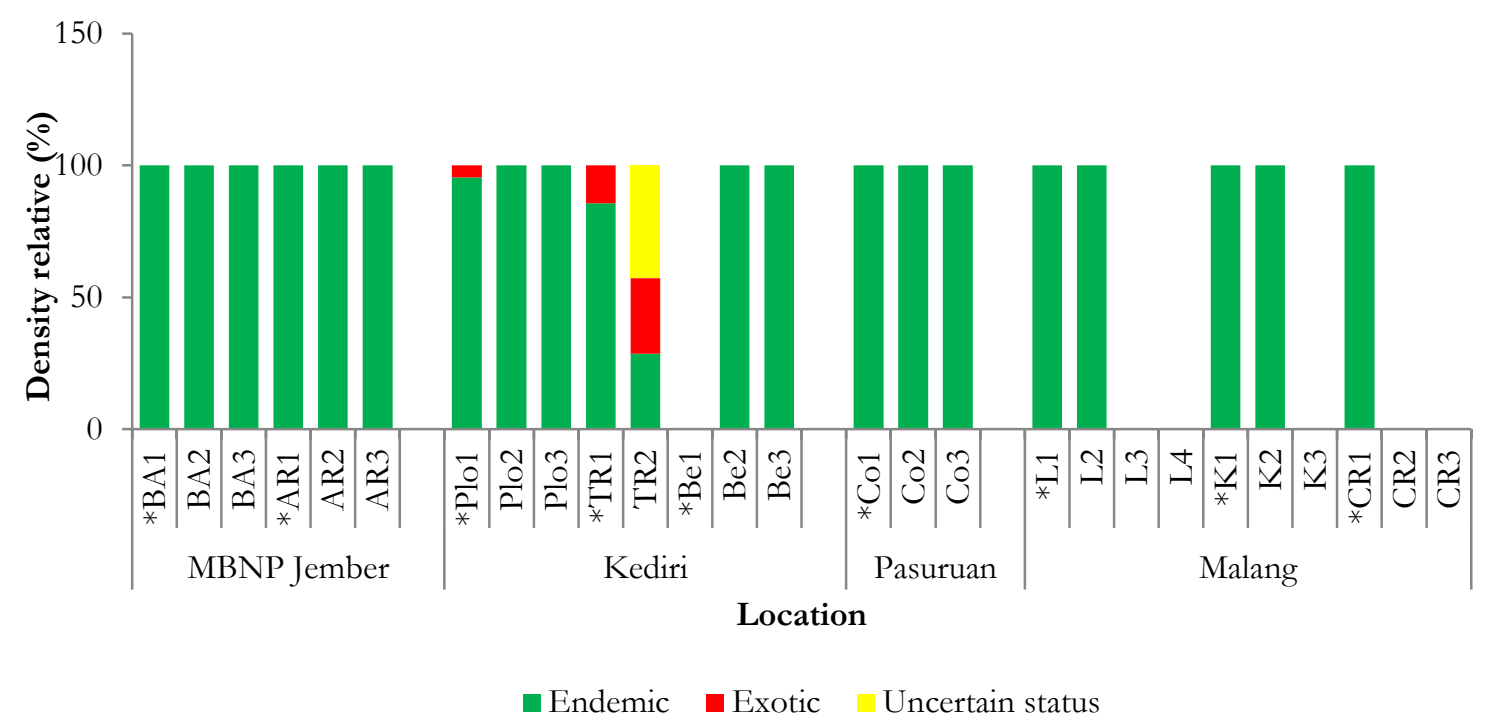

Figure 2. Endemism of riparian trees grown around of spring and its drain, East Java

Note: ${ }^{*}$ ) Spring; $\mathrm{BA}=$ Blok Aren; $\mathrm{AR}=$ Andongrejo; $\mathrm{Plo}=$ Plosolor; $\mathrm{TR}=$ Tempurejo; $\mathrm{Be}=$ Bendo; $\mathrm{Co}=$ Cowek; $\mathrm{L}$

= Lawang; $\mathrm{K}=$ Karangan; $\mathrm{CR}=$ Coban Rondo 


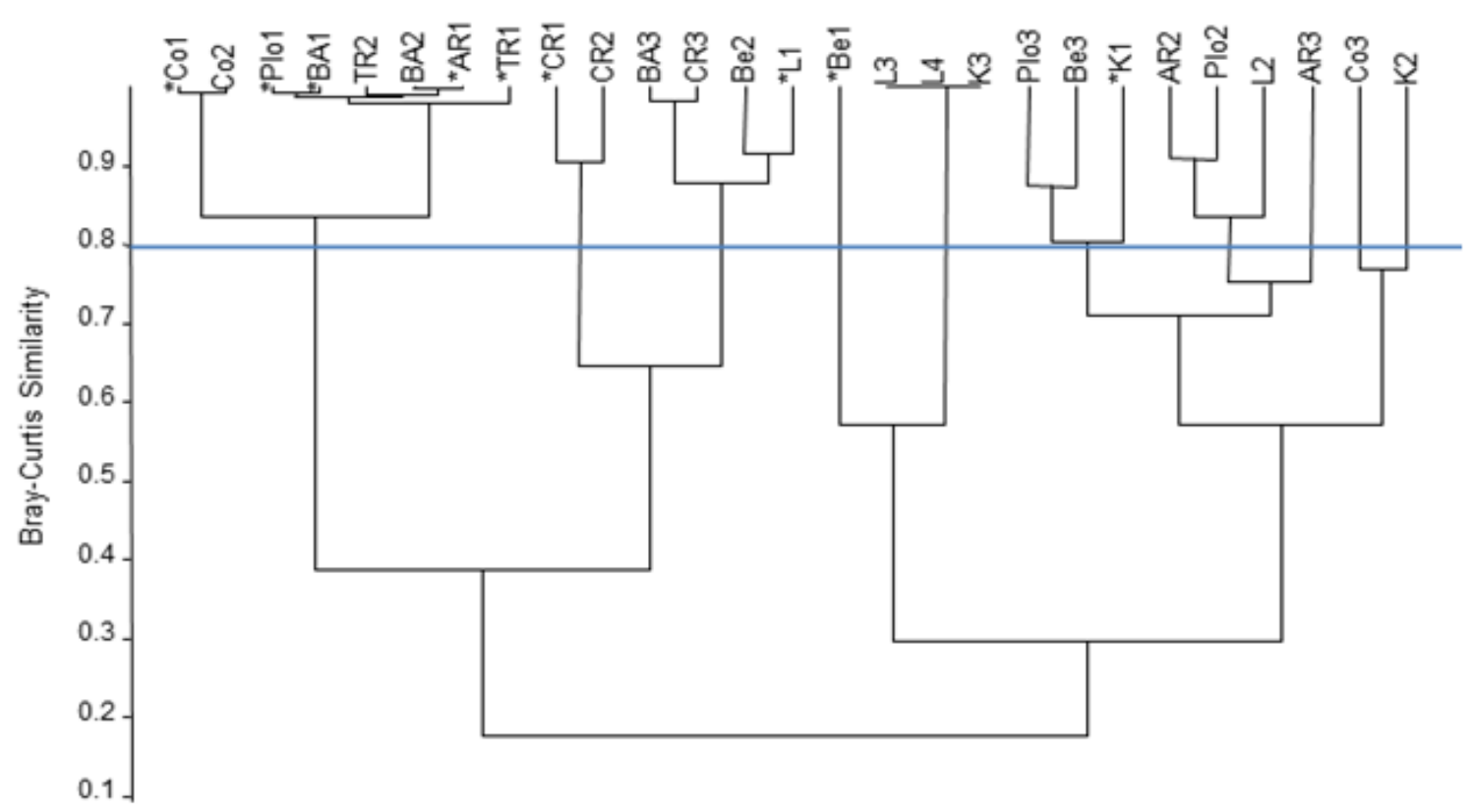

Figure 3. Cluster of diversity quality of riparian tree based on Bray-Curtis Similarity

Note: ${ }^{*}$ ) Spring; $\mathrm{BA}=$ Blok Aren; $\mathrm{AR}=$ Andongrejo; $\mathrm{Plo}=$ Plosolor; $\mathrm{TR}=$ Tempurejo; $\mathrm{Be}=\mathrm{Bendo}$; $\mathrm{Co}=$ Cowek; $\mathrm{L}$

= Lawang; $\mathrm{K}=$ Karangan; $\mathrm{CR}=$ Coban Rondo

\section{Profile of Water Quality}

The water quality in springs and their drains illustrated by $\mathrm{pH}$, electric conductivity, water transparency and color were all found to be various in 27 locations observed during the field research. The similarity value $(\mathrm{pH})$ of water in the springs and drains was identified normal, ranging from 6.5-8.8 (Figure 4a). Based on the researchers' examination, the value was found to still fulfill the standard of water quality according to Indonesian Government Regulation number 82, 2001, concerning on Water Quality Management and Water Pollution Control of Class I to Class IV, which is 6-9. In some locations where drains pass through rice fields coded as L4, K3, and CR2, the quality of water over reached the international quality standard stated by FAO, which is 6.5 to 8.4 . High $\mathrm{pH}$ above 8.5 is often caused by high concentration of bicarbonate $\left(\mathrm{HCO}^{3-}\right)$ and carbonate $\left(\mathrm{CO}_{3}{ }^{2-}\right)$, known as alkalinity. High carbonates cause calcium and magnesium ions to form insoluble minerals leaving sodium as the dominant ion in solution. As described in the sodium hazard section, this alkaline water could intensify the impact of high SAR water on acidic soil conditions [13].

The conductivity measurement of springs and their channels showed various results (Figure $4 \mathrm{~b})$. The lowest conductivity value was found at CR2, which was $52 \mu \mathrm{S} . \mathrm{cm}^{-1}$, while the highest was at Be3, which was $419 \mu \mathrm{S} . \mathrm{cm}^{-1}$. These values are categorized as good because they fulfill the conductivity standard of fresh water and irrigation. The higher the EC, the less water is avai- lable to plants, even though the soil may appear wet [13].

The levels of water transparency in 27 locations were classified into two: turbid and clear levels. Springs and their drains in general showed clear water $(66.67 \%)$, which were at BA1, AR1, Plo1, TR1, Be1, L1, K1, and CR1. Meanwhile, turbid water was found on drains of springs. The water transparency was affected by mud, plankton, and water color [14]. Many sediments coming into the body of water caused turbidity. The color of the water in 27 locations was classified into three: dark-brown, brown, and colorless. Springs and their drains had no color $(66.67 \%)$. The drains themselves were differentiated into dark-brown $(11.11 \%)$ located at BA3, Co3, and L4 and brown (22.22\%) at Plo3, Be2, $\mathrm{Be} 3, \mathrm{~L} 3, \mathrm{CR} 3$, and $\mathrm{K} 3$. The brown one was generally formed by sediment brought by stream causing the water transparency to decrease, while turbidity in-creased [15]. Bi-plot analysis (Figure $5 b)$ showed that water quality profile of the 27 locations were composed by four groups (supported by hierarchical cluster analysis in PAST). CR was characterized by high $\mathrm{pH}$, otherwise Plo, $\mathrm{Be}$, TR1, L1, and Co3 were characterized by high electric con-ductivity.

\section{Analysis of spearman correlation}

Based on Spearman correlation, there was negative correlation between riparian tree diversity and water quality. The water transparency had a negative correlation to turbidity. Lower turbidity is found in stations where we recorded 


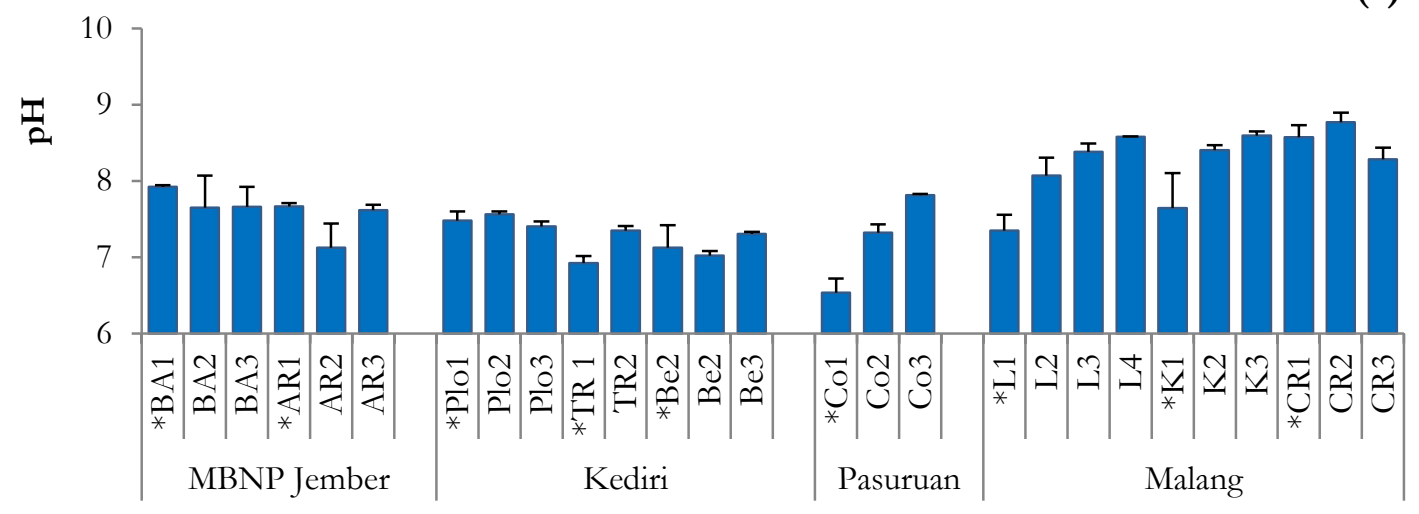

Location

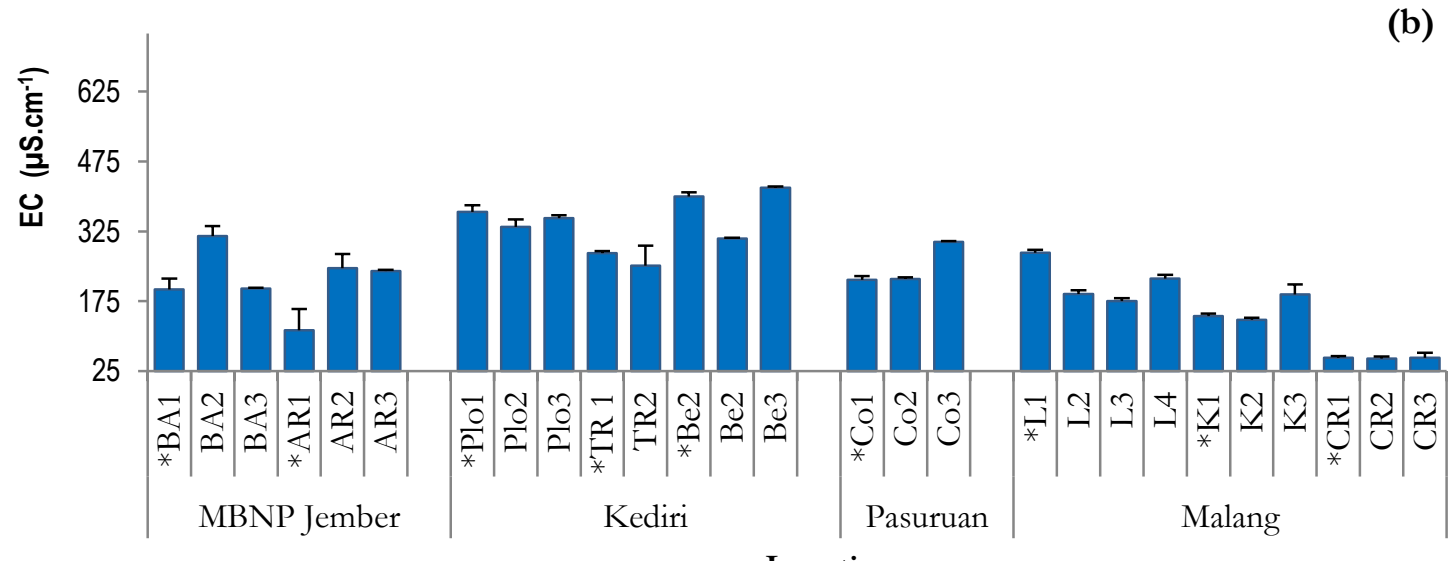

\section{Location}

Figure 4. Specific variation of water $\mathrm{pH}$ (a) and electric conductivity (b) of springs and their drains

Note: *) Spring; EC = Electric Conductivity; $\mathrm{BA}=$ Blok Aren; $\mathrm{AR}=$ Andongrejo; $\mathrm{Plo}=$ Plosolor; $\mathrm{TR}=$ Tempurejo; $\mathrm{Be}=$

Bendo; $\mathrm{Co}=$ Cowek; $\mathrm{L}=$ Lawang; $\mathrm{K}=$ Karangan; $\mathrm{CR}=$ Coban Rondo

Table 1. Profile of water quality in comparison with quality standard of water for irrigation

\begin{tabular}{|c|c|c|c|}
\hline No & Variable & Spring and its drains & Remark \\
\hline 1 & $\mathrm{pH}$ & $\begin{array}{ll}\text { - } & \text { 6.5-8.8 } \\
\text { - } \quad>8.4 \text { was found in L4, K3, CR1, and CR2 }\end{array}$ & $\begin{array}{l}\text { Good for fresh water } \\
\text { Poor for irrigation }\end{array}$ \\
\hline 2 & $\begin{array}{l}\text { Electric } \\
\text { conductivity }\end{array}$ & - $\quad 52 \mu \mathrm{S} . \mathrm{cm}^{-1}-419 \mu \mathrm{S} . \mathrm{cm}^{-1}$ & $\begin{array}{c}\text { Good for fresh water } \\
\text { and irrigation }\end{array}$ \\
\hline 3 & $\begin{array}{l}\text { Water } \\
\text { transparency }\end{array}$ & $\begin{array}{l}\text { Classified into two: turbid and clear levels } \\
\text { - } 33.33 \% \text { station was turbid (Co3, L3, L4, BA3, } \\
\text { Plo3, Be2, Co2, K3, CR3) } \\
\text { - } 66.67 \% \text { station was clear (BA1, BA2, AR1, } \\
\text { AR2, AR3,Plo1, Plo2, TR1, TR2, Be1, Co1, } \\
\text { Co2, L1, L2, K1, K2, CR1, CR2) }\end{array}$ & $\begin{array}{c}\text { Poor } \\
\text { Good for fresh water } \\
\text { and irrigation }\end{array}$ \\
\hline 4 & Color & $\begin{array}{l}\text { Classified into three: dark-brown, brown, and colorless } \\
\text { levels } \\
\text { - } 11.11 \% \text { station (BA3, Co3, L4) was dark- } \\
\text { brown } \\
\text { - } 22.22 \% \text { station (Plo3, Be2, L3, CR3, K3, } \\
\text { Be3) was brown } \\
\text { - } 66.67 \% \text { station (BA1, BA2, AR1, AR2, AR3, } \\
\text { Plo1, Plo2, TR1, TR2, Be1, Co1, Co2, L1, L2, } \\
\text { K1, K2, CR1, CR2) was colorless }\end{array}$ & $\begin{array}{c}\text { Poor } \\
\text { Poor } \\
\text { Good for fresh water } \\
\text { and irrigation }\end{array}$ \\
\hline
\end{tabular}

Note: *) Spring; BA = Blok Aren; AR = Andongrejo; Plo = Plosolor; TR = Tempurejo; Be = Bendo; Co = Cowek; L = Lawang; $\mathrm{K}=$ Karangan; $\mathrm{CR}=$ Coban Rondo 
(a)

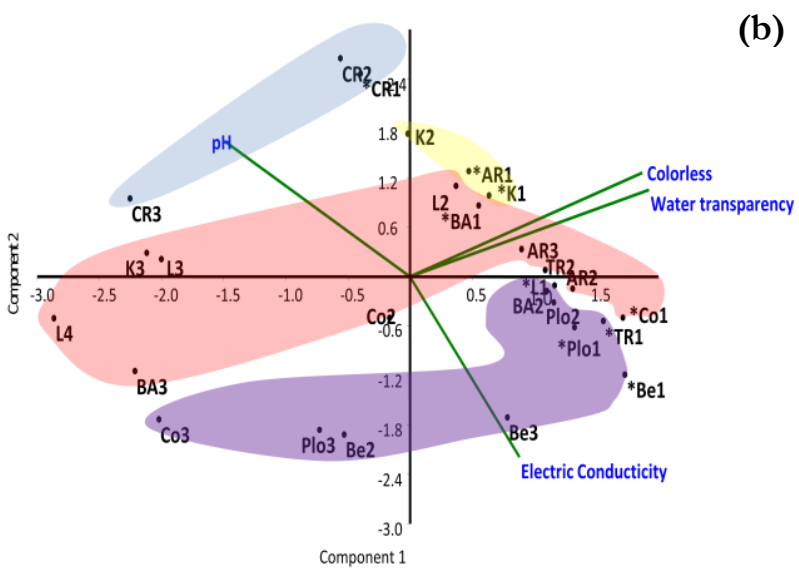

Figure 5. Grouping of water quality using Bray Curtis Similarity index (a) and bi-plot (b)

Note: ${ }^{*}$ ) Spring; $\mathrm{BA}=$ Blok Aren; $\mathrm{AR}=$ Andongrejo; $\mathrm{Plo}=$ Plosolor; $\mathrm{TR}=$ Tempurejo; $\mathrm{Be}=\mathrm{Bendo} ; \mathrm{Co}=\mathrm{Cowek} ; \mathrm{L}=$ Lawang; $\mathrm{K}=$ Karangan; $\mathrm{CR}=$ Coban Rondo

high richness of species, diversity index, width, and stratified riparian tree (Table 2). It shows that the riparian tree conserved on border spring or on its drains indicates high water quality compared to that at degraded border. The height of turbidity could degrade spring water quality. The riparian vegetation capable to prevent body of water from sediments as the result of the decrease of turbidity; while the water transparency increases [16]. The riparian tree protects the quality of water by means of its strong roots that can prevent land slide and erosion, filter of soluble nitrogen, phosphor, and various pollutants moving along slope [17]. On the otherhand, low $\mathrm{pH}$, higher water transparency and colorless water were found in stations where the researchers recorded high richness of riparian species, diversity index, width, and stratified tree. It is suspicious that the decrease in $\mathrm{pH}$ was related to detritivores activity by using litter of macrophyte due to respiration process [18].

\section{CONCLUSION}

Degradation of riparian trees has brought great impacts on water quality, which was increasing water turbidity. There was a positive correlation between riparian tree diversity and water transparency and color, but it had a negative correlation with water $\mathrm{pH}$. Low $\mathrm{pH}$, high water transparency and colorless water were found in stations having high species richness, diversity index, riparian width, and stratification of trees.

\section{ACKNOWLEDGEMENTS}

This research was financed by research Grant I-MHERE and supported by Dr. Endang
Arisoesilaningsih, Biology Department, Brawijaya University. We would like to thank Mr. Budi and Mr. Topan for their helpful assistance at the field for research areas in Meru Betiri National Park.

\section{REFERENCES}

1. Natta KA, Sinsin B, van der Maesen L (2002) Riparian forests, a unique but endangered ecosystem. Bot. Jahrb. Syst. 124 (1): 55-69.

2. Malik R, Shinwari ZK, Waheed H (2012) Linkages between spatial variations in riparian vegetation and floristics quality to the environmental heterogenity a case study of River Soan and its Associated Streams, Pakistan. Pak. J. Bot. 44: 187-197.

3. Kreye R, Wei M, Reksten D (1996) Defining the source area of water supply springs. Hydrology branch, ministry of environment, lands and parks. British Columbia.

4. Sen S, Mohapatra SK, Satpathy S, Rao G (2010) Characterization of hot water spring source isolated clones of bacteria and their industrial applicability. Int. J. Chem. Res. 2(1): 01-07.

5. Siwek J, Chelmicki W (2004) Geology and land use related pattern of spring water quality. Case study from the catchments of the Malopolska upland (S. Poland). Geologica acta: Int. J. Earth Sci. 2(2): 167-174.

6. Belsky JA, Matzke A, Uselman S (1999) Survey of livestock influences on stream and riparian ecosystems in the Western United States. J. Soil Water Conserv. 55: 419-431.

7. Twesigye C, Onywere SM, Getenga ZM, Mwakalila SS, Nakiranda JK (2011) The Impact of land use activities on vegetation cover and water quality in the Lake Victoria Watershed. J. Open Environt. Eng. 4: 66-77.

8. Sharma U (2001) Effects of farming system type on in situ groundwater recharge and quality in northeast India. Proceedings of a symposium heid during the Sixth IAHS Scientific Assembly 
at Maastricht, The Netherlands, July 2001. Editor: Gehrels H, Peters NE, Hoehn E, Jensen K, Leibundgut C, Griffioen J, Webb B, Zaadnoordijk WJ: 167-169.

9. Soejono (2011) Jenis pohon di sekitar mata air. UPT Balai Konservasi Tumbuhan Kebun Raya Purwodadi-LIPI. Purwodadi.

10. Sakai S., Kato M, Nagamasu (2000) Artocarpus (Moraceae)-Gall midge pollination mutualism mediated by a male-flower parasitic ungus. Am. J. Bot. 87(3): 440-445.

11. Cottee-Jones H, Whittaker RJ (2012) The keystone species concept: A critical appraisal. Frontiers of Biogeography 4 (3):117-127.

12. Solano R (2003) Riparian zone land use in indigenous and colonist communities of the Palcazu Basin, Peruvian Amazon. Department of Environmental Studies. Florida International University. Florida.

13. Bauder T, Waskom RM, Sutherland PL, Davis JG (2011) Irrigation water quality criteria. Colorado State University. Extension.
14. Kordi KMG, Tancung AB (2007) Pengelolaan kualitas air dalam budidaya perairan. Rineka Cipta. Jakarta.

15. Purnamaningtyas S, Tjahjo D (2008) Pengamatan kualitas air untuk mendukung perikanan di Waduk Cirata, Jawa Barat. J. Lit. Perikanan Indonesia 14(2):173-180.

16. Vigiak O, Ribolzi O, Pierret A, Valentin C, Sengtaheuanghoung O, Noble A (2007) Filtering of water pollutants by riparian vegetation: bamboo versus native grasses and rice in a Lao Catchment.Unasylva. 229 (58): 11-16.

17. Ward J, Dawson TE, Ehleringer JR (2002) Responses of Acer Negundo genders to inter annual differences in water availability determined from carbon isotope ratios of tree ring cellulose. Tree. Physiol. 22: 339-346.

18. Santino M, Bianchini Jr I, Okawa M (2010) The fate of Eichhornia azurea (Sw.) Kunth. detritus within a tropical reservoir. Acta Limnol. Bras. 22(2): 109-121. 